\title{
Peertechz
}

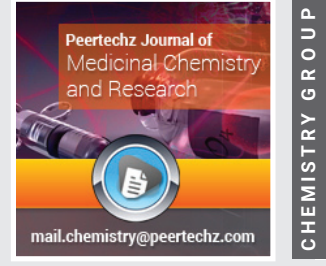

\section{Obtaining and studying} properties of biodestructable composite films based on polyethylene

Received: 10 November, 2020

Accepted: 09 December, 2020

Published: 11 December, 2020

*Corresponding author: IH Turdikulov, Institute of Polymer Chemistry and Physics, Tashkent, Kadry str. 7 b Uzbekistan, Tel: +998973420138;

E-mail: i.turdiqulov@mail.ru

Keywords: Polyolefins; Linear low-density polyethylene; Starch; Polymer composite; Films; Biodestruction; Biodegradable; Packaging materials

https://www.peertechz.com

Check for updates

\section{IH Turdikulov*, BN Mamadiyorov, MQ Saidmuhammedova} and AA Atakhanov

Institute of Polymer Chemistry and Physics, Tashkent kadry str. 7 b Uzbekistan

\begin{abstract}
At present, polyolefins are a heavily produced thermoplastic, and they are used in different industries. Approximately one-third of produced plastics are used in the packing industry, and this volume will only be increased in the future. The advantages of plastic packaging, such as strength, flexibility, moisture stability, comfort, safety and low cost, are accompanied by a disadvantage: they do not decompose in natural conditions, which causes considerable ecological problems, namely, plastic waste composes half of the domestic rubbish.
\end{abstract}

\section{Introduction}

At present, polyolefins are a heavily used of thermoplastic, and they are used in different industries. Approximately onethird of produced plastics are used in the packaging industry, and this volume will only be increased in the future $[1,2]$. The advantages of plastic packaging, such as strength, flexibility, moisture stability, comfort, safety and low cost, they also possess one disadvantage: they do not decompose in natural conditions, which causes considerable ecological problems, namely, plastic waste composes half of the domestic rubbish.

Polyethylene (PE) and Polypropylene (PP) are widely used polyolefins for the manufacturing of packaging materials [3]. Al-Salem, S., Lettieri P., Baeyens, M. J. [4] found that solid domestic waste lost its consumption properties early; their traditional methods of utilization involve dumping or burning. When they are burned, harmful compounds are emitted into the atmosphere. The use of two-component polymers for decomposition can be a solution to environmental pollution by polymer waste. Biodegradable polymer materials can be decomposed during a definite period of time to lowmolecular-weight compounds that can be used by different microorganisms under the action of different factors (e.g., the temperature, UV irradiation, water exposure and oxygen exposure). Natural polymers and their modified based on starch cellulose, chitin [5,6] and polymers synthesized from renewable raw materials using biotechnological methods, namely, polyhydroxyalkanoates, polylactides, and degradable aliphatic polyesters from oil-chemical raw materials, such as polycaprolactam and polyesteramides [7-9], can be used as initial materials to obtain biodegradable polymer materials.

However, biodegradable polymers have disadvantages, such as relatively high cost, low mechanical strength, operational characteristics, and low thermostability, which have prevented the expansion of their widespread use in the packing industry. At present, it is not possible to implement all demands for their use, which can introduce limits or exclude the use of biopolymers [10].

To overcome these limitations, the most effective methods involve the use of compositional materials based on polyolefins, including different fillers, such as natural polymers [11-13], and the use of oxo-additions to initiate the decomposition of polyolefins in environmental conditions. 
The oxo-decomposition of plastics is based on the oxidation of polymer materials under the action of external environmental factors (e.g., UV irradiation and exposure to $\mathrm{O}_{2}$ in air) and formation of low molecular weight compounds. In the literature, there are many investigations [14-16] of decomposable compositions of polyolefins and oxo-additives, which are comonomers with functional groups that promote photodestruction (e.g., vinylketones and $\mathrm{CO}$ ) or photocatalysts (compounds of metals with a variable valence, like $\mathrm{Fe}, \mathrm{Ni}, \mathrm{Co}$, and $\mathrm{Mn}$ )

Additionally, to improve the biodegradability of polymers, investigations have been carried out that involve grafting hydrophilic compounds in the structure of synthetical polymers by copolymerization, which changes the chemical and physical properties of the initial polymers [17-20].

Materials based on polyolefins with natural additions, such as starch [21,22] arboreal meal [23], natural rubber [24], chitosan [23], cellulose [26] and different natural fibres $[27,28]$, are widely used.

However, such mixtures are not fully biodegradable because under the action of natural factors, they decompose to form dispersion products, but at this point, their polymer base has remained undecomposed [10]. These materials did not decompose completely under natural conditions, but the structure of the packaging materials was destroyed. These fillers decomposed completely, but the synthetic part was scattered as a powder, preventing the accumulation of large solid waste. Such materials can be referred to as 'biodegradable materials'.

The addition of natural fillers enables biodegradability but also substitution of oil-based raw materials that are not renewed and a decrease in the cost of obtained products [29].

The aim of this work is to obtain biodegradable polymer films based on PE and starch and different types of nanocellulose and to investigate their properties, physicochemical characteristics and biodegradability.

\section{Material and methods}

\section{Materials}

The materials included low-density linear PE from the Shurtan Gas Chemical Complex (Uzbekistan) at mark F-0320 with a melting flow index of $0.31 \mathrm{~g} / 10 \mathrm{~min}\left(190^{\circ} \mathrm{C}, 2,16 \mathrm{~kg}\right)$; industrial sample of corn starch $\left(\mathrm{St}_{\mathrm{c}}\right)$, potatoes starch $\left(\mathrm{St}_{\mathrm{p}}\right)$, and rice starch $\left(\mathrm{St}_{\mathrm{r}}\right)$; and nanocellulose $(\mathrm{NC})$ obtained from cotton cellulose by acid hydrolysis. Their base compositions were the objects of this investigation.

\section{Methods}

The preparation of the compositions was carried out under the action of a high-temperature laboratory rotary mixer by Brabender. Vasilenko, A. Yu. [30] showed that this method is effective for obtaining polymer compositions with improved exploitation properties and provided the best distribution of the filler in the polymer matrix [31].
Fabrication of the components was carried out at a temperature of $190 \pm 2{ }^{\circ} \mathrm{C}$ and rotor rotation of 30 turnovers/ min. In the mixing chamber, in accordance with the desired composition, the PE with filler was loaded and then mixed for $20 \mathrm{~min}$. After mixing, the obtained composite was removed from the mixer and cooled in air at $25 \pm 2^{\circ} \mathrm{C}$. The content of the filler in the composites was varied as follows (mass \%): 5,10 , 20,30 and 40 .

The blends were compression molded into sheets $2 \mathrm{~mm}$ thick using $20 \times 20 \mathrm{~cm}$ window frame molds in Hydraulic Press, Model CMP 30. The platens of the press were heated to $190^{\circ} \mathrm{C}$. The window was placed between two glazed sheets, already sprayed with silicon mold release agent on the contact surface and filled with preweighed material. The assembly was then placed in the hydraulic press and initially heated for 6 min without applying any pressure to ensure uniform heat flow through the material. The temperature was maintained at $190^{\circ} \mathrm{C}$ for all the compositions of blends for $10 \mathrm{~min}$ at a pressure of $25 \mathrm{t}$, which was applied gradually during the first $5 \mathrm{~min}$. The sheet thus obtained was removed from the press after cooling to room temperature. Round film samples with a diameter of 6 sm and thickness of $130 \pm 10 \mathrm{mkm}$ were obtained.

An investigation of the structure of the obtained films was carried out on an optical microscope by Motic. The transparency of the films was determined on a SKF 120C fully automatic spectrophotometer. The melt flow index (MFI) of the samples was investigated on a DH-MI-BP tester. The mechanical properties of the films were determined on a TM2101tensile testing machine. The rheology of the composites was investigated with a rheostat.

The biodegradation of the obtained samples was determined by two methods. In the first method, films under definite conditions were subjected to the action of a natural complex of soil microflora, and the stability of the microbiological decomposition as a function of the outer appearance and mechanical strength was determined. The testing mixture (soil) was prepared from sand horse manure and garden earth in equal quantities by mass. The soil before tests was sustained for 2 months at a temperature of $20 \pm 5^{\circ} \mathrm{C}$ and moisture of $30 \%$.

Changes in the mass and outer appearance of the film samples after exposure to water for a definite period of time were determined with the second method.

\section{Results and discussion}

Obtaining composites of PE and starch by thermomechanical mixing requires a highly uniform distribution of starch molecules in the volume of melted PE. The presence of starch in the volume of $\mathrm{PE}$ influenced the processing due to the transmission of the composite in the liquid state. Therefore, it is very important to investigate the behaviour of composites in the liquid state with air to determine the peculiarities of structural and phase transformations in the flow.

$\mathrm{PE}$ is classical thermoplastic that involves transferring its granules in the melted state in the range from $150-200^{\circ} \mathrm{C}$. When PE is higher $200^{\circ} \mathrm{C}$, it can undergo thermo-oxidation. 
Decreasing the temperature to $150^{\circ} \mathrm{C}$ resulted in the loss of fluidity of the melt, and in the temperature range of $80^{\circ} \mathrm{C}, \mathrm{PE}$ hardened. For this reason, the processing of $\mathrm{PE}$ as a liquid-solid body is important. The results of the PE starch composites in shear flow are presented as the dependence of the rate gradient $(\gamma)$ on the temperature $\left(\mathrm{t},{ }^{\circ} \mathrm{C}\right)$ (Figure 1 ). With a temperature above $140^{\circ} \mathrm{C}$, samples started to flow, which indicates that it was melting. From $150^{\circ} \mathrm{C}$ to $180^{\circ} \mathrm{C}$, the rate gradient monotonically increased for the PE from 0.56 to $1.2 \mathrm{c}-1$ and for the PE-starch composite from 0.5 to $1.1 \mathrm{c}-1$. Such a change in the frequency of the rate gradient with increasing temperature indicates that the fluidity of the PE melt increased owing to decreasing intermolecular bonds under the action of heat on the moving flow. In the case of the composites, a decrease in the gradient was caused by the influence of the starch on the fluidity, that is, by increasing the viscosity of the melt of this system. Decreasing the temperature was accompanied by a decrease in the velocity gradient, and at $\mathrm{t}=100^{\circ} \mathrm{C}$, the fluidity of the melts practically stopped. In the region of $t<80^{\circ} \mathrm{C}$, the melts passed into the solid state. In general, in the temperature range from $145-175^{\circ} \mathrm{C}$, the rate gradient of melting samples changed insignificantly. In this temperature interval, PE:starch can be processed as PE as a thermoplastic material.

An analysis of the MFI changes as a function of the PE:filler ratio and its nature allowed us to determine changes in the rheological parameters (Table 1).

As shown in Table 1, increasing the content (mass \%) of the fillers in the composites decreased the MFI, that is, the compositions had a high viscosity. The lowest viscosity was observed for the composite with a filler content of 5 mass \% in the polymer matrix. High MFI values were observed when a high filler content ( 40 mass \%) of corn starch was used, and the dimensions and form of the filler particles obviously influenced the viscosity of the composites to a great degree. Composites containing a highly dispersed filler had a decreased viscosity.

Optical investigations of the composite films showed that with increasing filler content, an increased number of large particles (agglomerates) were present in the polymer matrix. After an increased time of component mixing, a uniform distribution of the filler in the matrix of PE was observed (Figure 2).

The presence of starch in the composites influenced the transparency of the films. It was shown that with increasing filler content in the composites, the transparency of the films decreased (Table 2) Figure 3.

It was found that the index of strength limit (ISL) at tension was higher for compositions $\mathrm{PE} / \mathrm{St}_{\mathrm{c}}$ in comparison with other samples at the same content of natural fillers. A decrease in the strength characteristics of the compositional films was observed following raw $P E / S t_{c}>P E / S t_{p}>P E / S t_{r}$. In films obtained by the addition of nanocellulose (NC), the same raw of decreasing mechanical strength was preserve (Table 3).

The ability of composite materials based on polyolefin and natural fillers to decompose and be assimilated by

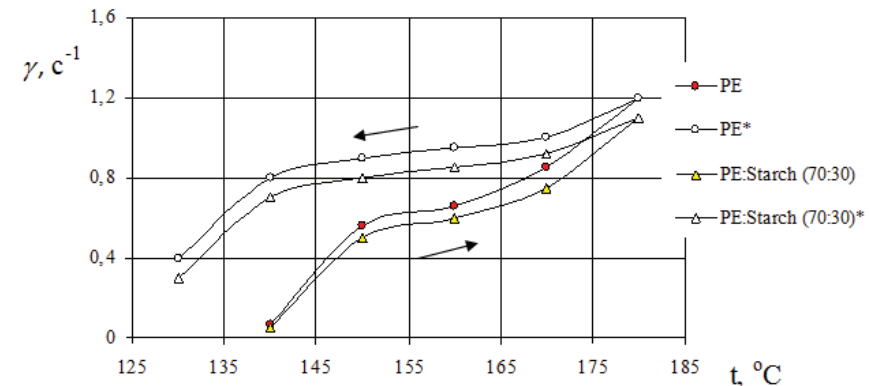

Figure 1: Dependence of rate gradient $(\gamma)$ on the temperature $\left({ }^{\circ} \mathrm{C}\right)$ for PE and composite PE:starch with a composition of 70:30 (mass. \%).

\begin{tabular}{|c|c|c|c|c|c|c|c|}
\hline Composition & \multicolumn{5}{|c|}{$\mathrm{PE} / \mathrm{St}_{\mathrm{c}}$} & \multicolumn{2}{|c|}{$\mathrm{PE} / \mathrm{St}_{\mathrm{c}} / \mathrm{NC}$} \\
\hline Ratio & $95 / 5$ & $90 / 10$ & $80 / 20$ & $70 / 30$ & $60 / 40$ & $80 / 10 / 10$ & $70 / 15 / 15$ \\
\hline $\mathrm{MFI}(\mathrm{g} / 10 \mathrm{~min})$ & 3,08 & 2,83 & 2,52 & 2,10 & 1,81 & 2,40 & 1,80 \\
\hline Composition & \multicolumn{5}{|c|}{$P E / S t_{p}$} & \multicolumn{2}{|c|}{$P E / S t_{p} / \mathrm{NC}$} \\
\hline Ratio & $95 / 5$ & $90 / 10$ & $80 / 20$ & $70 / 30$ & $60 / 40$ & $80 / 10 / 10$ & $70 / 15 / 15$ \\
\hline $\mathrm{MFI}(\mathrm{g} / 10 \mathrm{~min})$ & 3.09 & 2.79 & 2.44 & 2.10 & 1.76 & 2,32 & 2,34 \\
\hline Composition & \multicolumn{5}{|c|}{$P E / S t_{r}$} & \multicolumn{2}{|c|}{$P E / S t_{r} / \mathrm{NC}$} \\
\hline Ratio & $95 / 5$ & $90 / 10$ & $80 / 20$ & $70 / 30$ & $60 / 40$ & $80 / 10 / 10$ & $70 / 15 / 15$ \\
\hline $\mathrm{MFI}(\mathrm{g} / 10 \mathrm{~min})$ & 3.04 & 2.84 & 2.40 & 1.97 & 1.75 & 2,22 & 2,16 \\
\hline
\end{tabular}
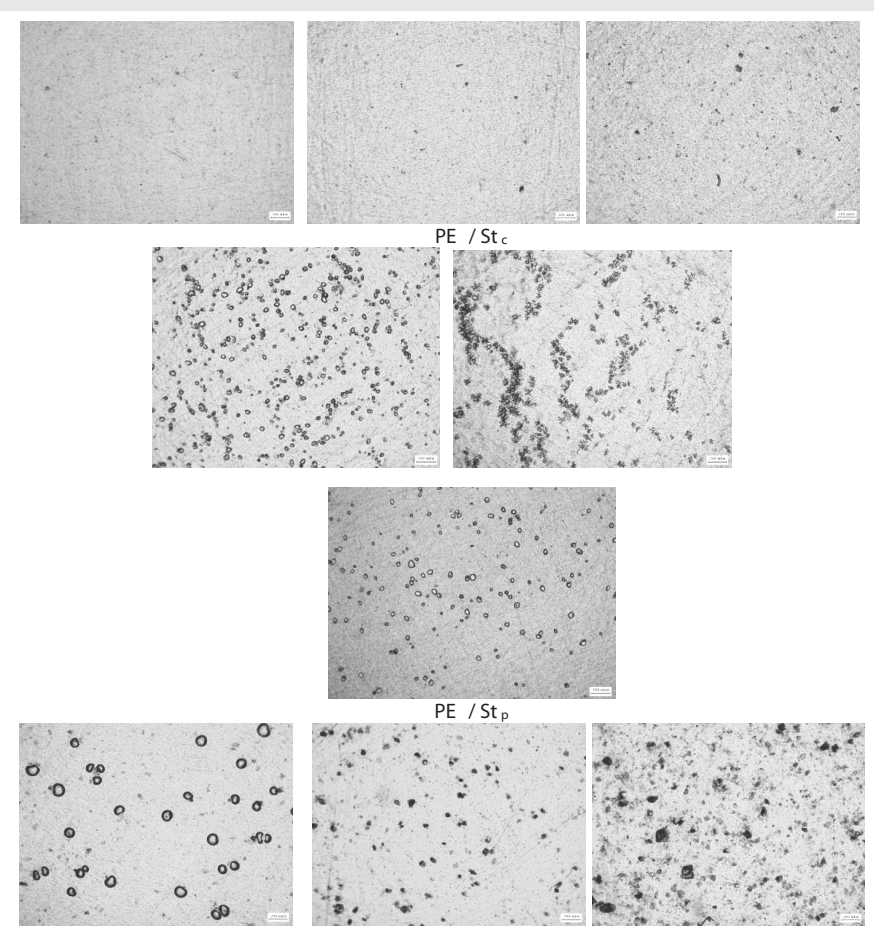

Figure 2: Optical photographs of the PE/starch composite films. From left to right, the content of starch in compositions was (mass \%) $5,10,20,30$, and 40.

microorganisms is dependent on the characteristics of the polymeric matrix and filler, which determines the structure of the final product. For example, polyolefins with a low molecular mass that possess a branched structure and a low degree of crystallites have an improved biodegradability. However, to a considerable degree, the biodegradability of composites 
is determined by the content and chemical composition of the filler and the dimensional parameters and form of the particles. Polymeric materials in the environment are subjected to physical, chemical and biological factors.

One of the factors determining the low ability of polyolefins to biodegrade is their low ability to absorb water, which is necessary for the development of microorganisms. Film samples were tested for water action (Figure 4).

In all cases, a monotonic change in the mass was not observed. After 40-60 days of testing, the mass of films

Table 2: Index of transparency of the obtained composite films.

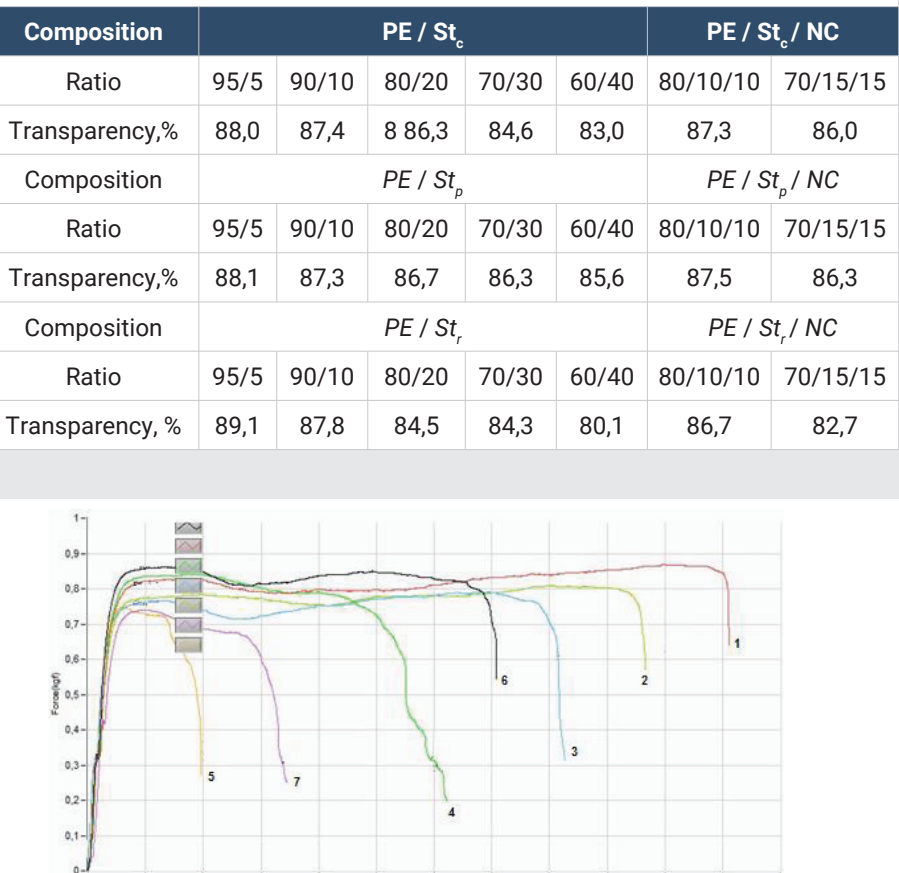

PE / St c: $1-95 / 5,2-90 / 10,3-80 / 20,4-70 / 30$, and $5-60 / 40$; and PE / St $c$ / NC: $6-80 / 10 / 10$ and $7-70 / 15 / 15$

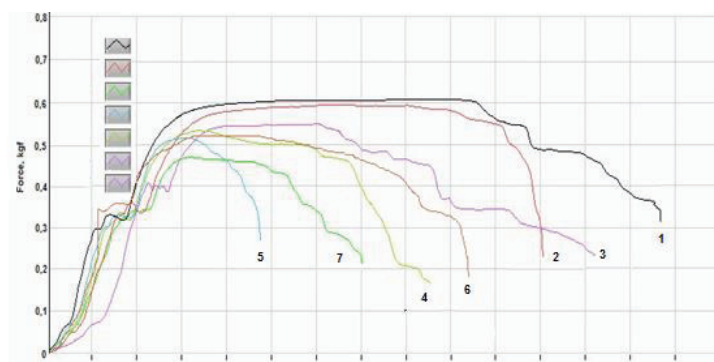

PE / Stp: $1-95 / 5,2-90 / 10,3-80 / 20,4-70 / 30$, and $5-60 / 40$; and PE / St $p_{\mathrm{p}} / \mathrm{NC}: 6-80 / 10 / 10$ and $7-70 / 15 / 15$

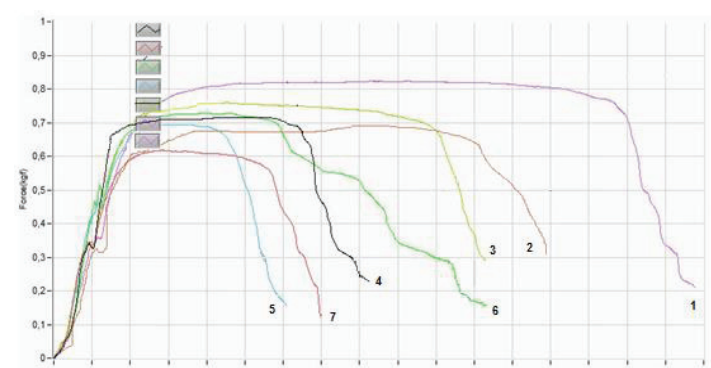

PE / St $r: 1$ - 95/5, 2 - 90/10, $3-80 / 20,4-70 / 30$, and 5 - 60/40; and PE / St $t_{r}$ NC: 6 - 80/10/10 and 7 - 70/15/15.

Figure 3: Physico-mechanical investigations of composite films.
Table 3: Physico-chemical characteristics of the composite films.

\begin{tabular}{|c|c|c|c|c|c|c|c|}
\hline Composition & \multicolumn{5}{|c|}{ PE / St } & \multicolumn{2}{|c|}{ PE / St / NC } \\
\hline Ratio & $95 / 5$ & $90 / 10$ & $80 / 20$ & $70 / 30$ & $60 / 40$ & $80 / 10 / 10$ & $70 / 15 / 15$ \\
\hline ISL, MPa & 7,9 & 7,1 & 6,6 & 6,1 & 5,4 & 6,8 & 6,2 \\
\hline Young's Modulus & 118,2 & 115,9 & 110,2 & 108,2 & 87,4 & 111,6 & 112,2 \\
\hline Elongation, \% & 50,0 & 60,0 & 55,0 & 35,0 & 30,0 & 45,0 & 25,0 \\
\hline Composition & \multicolumn{5}{|c|}{$P E / S t_{p}$} & \multicolumn{2}{|c|}{$P E / S t_{p} / N C$} \\
\hline Ratio & $95 / 5$ & $90 / 10$ & $80 / 20$ & $70 / 30$ & $60 / 40$ & $80 / 10 / 10$ & $70 / 15 / 15$ \\
\hline ISL, MPa & 6,7 & 6,1 & 4,8 & 4,1 & 3,9 & 5,9 & 5,5 \\
\hline Young's Modulus & 110,9 & 102,9 & 98,1 & 96,6 & 83,9 & 98,1 & 97,9 \\
\hline Elongation, \% & 30,0 & 22,0 & 26,0 & 21,0 & 15,0 & 53,0 & 28,0 \\
\hline Composition & \multicolumn{5}{|c|}{$P E / S t_{r}$} & \multicolumn{2}{|l|}{$P E / S t_{r} / N C$} \\
\hline Ratio & $95 / 5$ & $90 / 10$ & $80 / 20$ & $70 / 30$ & $60 / 40$ & $80 / 10 / 10$ & $70 / 15 / 15$ \\
\hline ISL, MPa & 6,2 & 5,4 & 4,0 & 3,3 & 3,0 & 5,3 & 4,5 \\
\hline Young's Modulus & 115,5 & 108,2 & 104,1 & 103,5 & 93,5 & 108,6 & 107,3 \\
\hline Elongation, \% & 22,0 & 18,0 & 10,0 & 9,0 & 10,0 & 18,0 & 15,0 \\
\hline
\end{tabular}

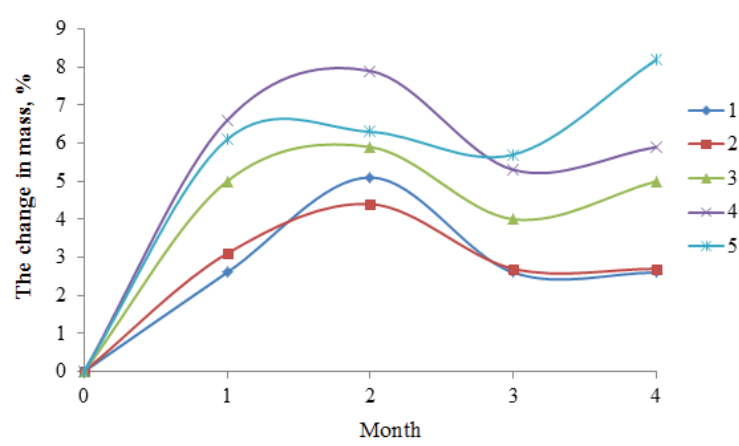

$\mathrm{PE} / \mathrm{St}_{\mathrm{c}}$

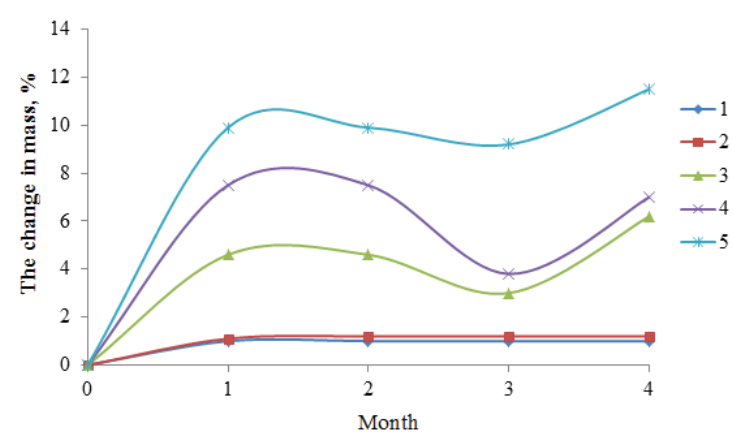

$\mathrm{PE} / \mathrm{St} \mathrm{p}$

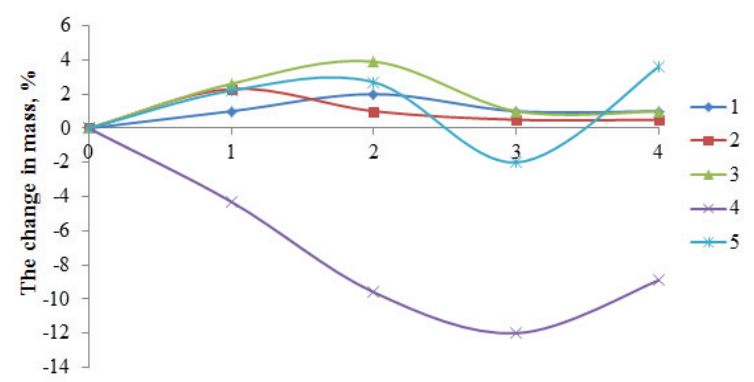

Month

$\mathrm{PE} / \mathrm{St}_{\mathrm{r}}$

Figure 4: The film mass as a function of the duration of the water content of the filler in the composition (mass \%): $1-5,2-10,3-20,4-30$, and $5-40$.

Citation: Turdikulov IH, Mamadiyorov BN, Saidmuhammedova MQ, Atakhanov AA (2020) Obtaining and studying properties of biodestructable composite films based on polyethylene. Open Journal of Chemistry 6(1): 030-036. DOI: https://dx.doi.org/10.17352/ojc.000021 
increased $1.5-11 \%$ depending on type of filler. Polyolefin with fillers had an increased water absorption and swelling compared with those for the PE without fillers, which increased the accessibility for the microorganisms. Fermentation occurred due to the microorganisms and moisture of the soil.

On some curves, of the mass increase was connected to the swelling of surface layers, after which there was a sharp decrease in the mass.

This is connected with the removal of low molecular weight fractions on the surface during the first days, and then the process stabilized. In some cases, swelling occurred due to penetration of the solvent in intermolecular spaces.

The decrease in the mass of the composites depended on the portion of soluble components, dimensions of the filler particles and availability of the fillers in the polymer matrix (i.e., the concentration).

The films were also buried in soil, and then, the strength after 60 days were investigated (Figure 5).

As shown in Figure 5, the top surfaces of the films changed, and bioaccumulation of microorganisms on the surfaces of the polymer materials was observed. Natural fillers, owing to their hydrophilicity and assimilation by microorganisms, increased the microorganism adhesion on the polyolefin surfaces, which accelerated the attachment of microorganisms on the surface of the composites due to bioaccumulation. Free radicals forming in the process of filler degradation initiated the destruction of the polyolefin matrix.

The physico-chemical properties of the composite films after composting for 60 days in specially prepared biohumus were investigated. It was determined that the mechanical properties decreased after composting due to degradation of the polymer. An analysis of the physico-chemical results (Table 4) showed that the tensile strength in the longitudinal direction decreased by $20 \%$ and more.

This results are explained by the fact that under the action of the microflora, the structure of the composites was lost. An investigation of the physico-mechanical properties of the samples showed qualitative changes in the structure of the composite materials during the process of biodegradation. Microfungal colonies promoted the decomposition of the biocomponents entering the polymer materials. The accumulation of fragments of the composite materials by the soil microorganisms and their degradation decrease the strength of the composites.

As preliminary optical investigations of the composite films after 90 days showed (Figure 6), damage to the film structures occurred due to the formation of holes (biological corrosion). These holes increased the sensitivity of the materials to the actions of the chemical and mechanical factors and increased their decomposition.

It is necessary to note that the index of biodegradation of the PE did not change during the entire period of the
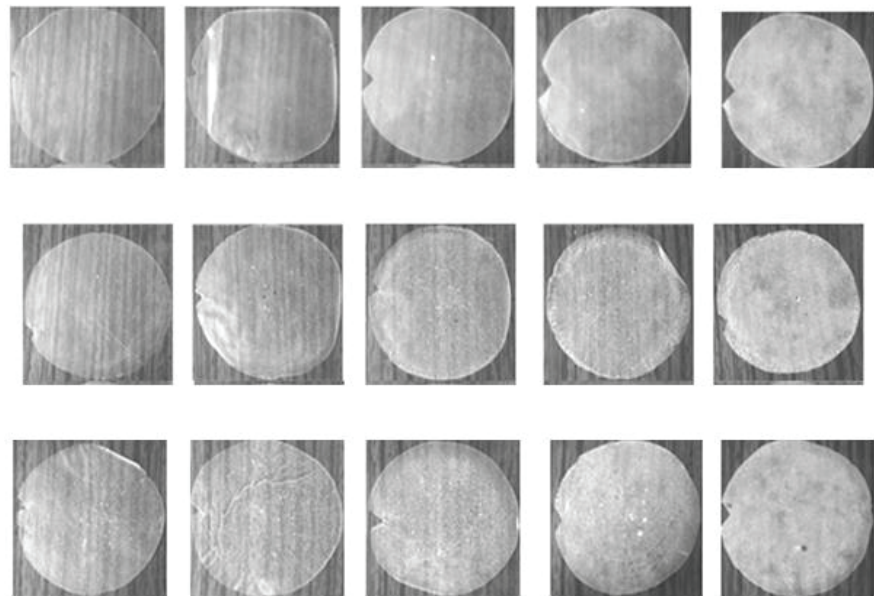

Figure 5: Changes in the outer appearance of films after composting. From top to bottom: PE / St $t_{c}, P E / \mathrm{St}_{\mathrm{p}}$, and PE/ St

Table 4: Physico-mechanical characteristics of compositional films before and after composting.

\begin{tabular}{|c|c|c|c|c|c|}
\hline Composition & \multicolumn{5}{|c|}{$P E / \mathbf{S t}_{c}$} \\
\hline ratio & $95 / 5$ & $90 / 10$ & $80 / 20$ & $70 / 30$ & $60 / 40$ \\
\hline ISF, MPa (before) & 7,9 & 7,1 & 6,6 & 6,1 & 5,4 \\
\hline ISF, MPa (after) & 6,0 & 5,1 & 5,0 & 4,9 & 4,5 \\
\hline Composition & & & $P E / S t_{p}$ & \\
\hline ratio & $95 / 5$ & $90 / 10$ & $80 / 20$ & $70 / 30$ & $60 / 40$ \\
\hline ISF, MPa (before) & 6,7 & 6,1 & 4,8 & 4,1 & 3,9 \\
\hline ISF, MPa (after) & 6,3 & 5,0 & 4,2 & 3,6 & 2,7 \\
\hline Composition & & & $P E / S t_{r}$ & & \\
\hline ratio & $95 / 5$ & $90 / 10$ & $80 / 20$ & $70 / 30$ & $60 / 40$ \\
\hline ISF, MPa (before) & 6,2 & 5,4 & 4,0 & 3,3 & 3,0 \\
\hline ISF, MPa (after) & 4,5 & 3,6 & 3,4 & 2,5 & 1,5 \\
\hline
\end{tabular}
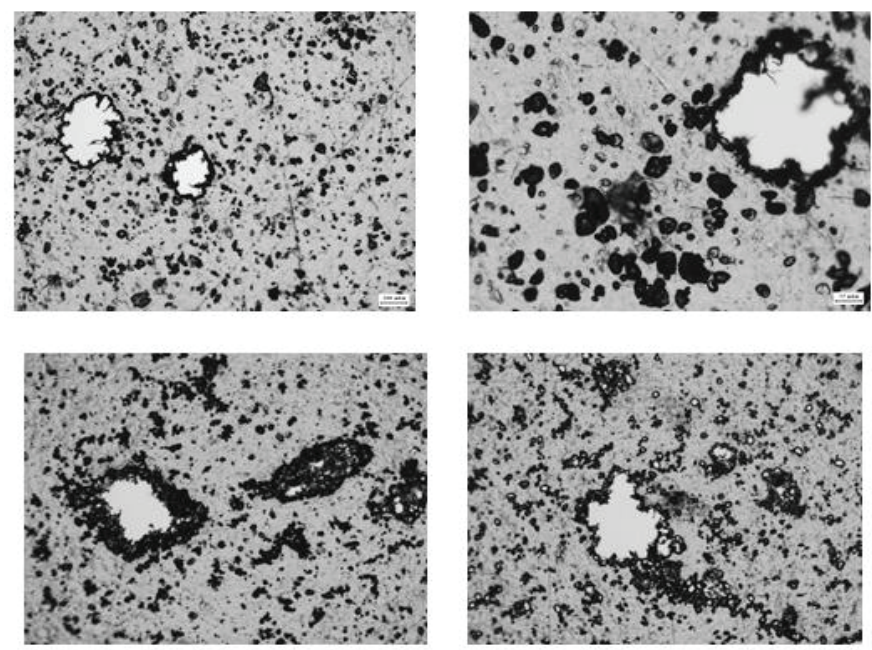

Figure 6: Microphotographs of compositional film after 90 days of during in soil scale $1 \times 70$ мкм

investigation. The biodegradation of the composites after being buried for 90 days in the soil ranged from $30-50 \%$ The damage included changes in the colour, a decrease in the mass biological accumulation of biomaterials in the samples, oxidation of the polymer with accumulation of end carboxylic 
groups and mechanical destruction. Mastalygina Ye [32] showed that changes in the colour can be due to removal of fillers that are soluble in water and can undergo hydrolysis; the colour change may also be due to the accumulation of melanintype pigments, which are products of the metabolism of certain moielialic fungi and bacteria.

\section{Conclusion}

Biodegradable compositional films based on PE and natural fillers (different starches and nanocellulose) were fabricated. The filler composition was varied from 5 to 40 mass $\%$. A wide range of compositions allowed us to fabricate materials with different structures and to determine precise changes in the properties of the mixtures ( materials) during transmission from one component composition to another.

The rheological behaviour of a PE melt with starch during shear flow was investigated, and the range of temperatures

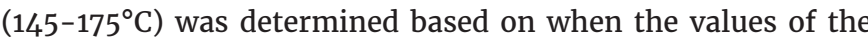
rate gradients of the melted samples did not change to a great degree. In this temperature interval, the composites could be processed as thermoplastic PE is typically processed.

Analysis of the MFI of the compositions showed that the lowest viscosity during melting was observed for compositions containing 5 mass \% filler in the polymer matrix. High values of the MFI at low fillers contents ( $40 \%$ and more) were observed using corn starch. The micrographs of the obtained composites clearly showed filler particles, and at this point, their form depended on their nature. With increasing filler content in the composites, additional large particles in the polymer matrix were observed. With increasing component mixing time, a more uniform distribution of the filler in the PE matrix was observed.

An investigation of the mechanical properties of the films showed that the introduction of the filler in the composites decreased their strength. This was observed following the fact that the higher the filler content was, the lower the rupture strength of the films.

The filled polyolefins had higher indexes of water adsorption and swelling than those of the PE, which increased the ability of these materials to possess microorganisms. After 60 days of composting the films in a special humus, the bioaccumulation of microorganisms on the polymer materials changed the surfaces. It was determined that the mechanical properties after composting decreased due to the destruction of the polymer matrixes. An analysis of the results of the physico-mechanical investigations showed that for a change in the composition, the strain in the longitudinal direction decreased by more than $20 \%$. This can be explained by the fact that under the action of microflora, the structure was loosened.

An investigation of the physico-mechanical properties of the samples visually demonstrated the changes in the structure of the composites during biodegradation. After 90 days of exposure to soil, the film structure was damaged because of the formation of holes. The materials became more receptive to the action of chemical and mechanical factors, which increased the biodegradation.

\section{References}

1. Ellen MacArthur Foundation and McKinsey and Company. The New Plastics Economy-Rethinking the Future of Plastics (Online), 2016

2. An analysis of European plastics production, demand and waste data. Final web version Plastics the Facts. Link: https://bit.ly/3qIXMGP

3. Soroudi A, Jakubowicz I (2013) Recycling of bioplastics, their blends and biocomposites. Eur Polym J 49: 2839-2858. Link: https://bit.ly/33WZHOe

4. Al-Salem S, Lettieri P, Baeyens MJ (2009) Recycling and recovery routes of plastic solid waste (PSW): a review. Waste Management 29: 2625-2643. Link: https://bit.ly/2WcB8sB

5. Ibrahim H, Farag M, Megahed H, Mehanny S (2014) Characteristics of starchbased biodegradable composites reinforced with date palm and flax fibers. Carbohyd Polym 101: 11-19. Link: https://bit.ly/33YtXZe

6. Lu DR, Xiao CM, Xu SJ (2009) Starch-based completely biodegradable polymer materials. eXPRESS Polymer Letters 3: 366-375. Link: https://bit.ly/37Ny2Ax

7. Muthuraj R, Misra M, Mohanty AK (2017) Biodegradable compatibilized polymer blends for packaging applications: A literature review. Journal of Applied Polymer Science 45726. Link: https://bit.ly/3nh5WEt

8. Takesayev MS, Yermeyeva LM (2009) Proizvodstvo biopolimerov kak odin putey resheniya problem ekologii i APK. [The production of biopolymers as one of the ways to solve the problems of ecology and agribusiness]. Alma-Ata: SC STI Publ., 200s [in Russian].

9. Azizov AG, Ibragimova MD, Aliyeva LI (2012) Biorazlagayemyye sinteticheskiye polimery (obzor) [Biodegradable synthetic polymers (review)]. Khimiya v interesakh ustoychivogo razvitiya - Chemistry for Sustainable Development 20: 385-393 [in Russian].

10. Abramov VV, Chalaya NM (2019) Biopolimery: spaseniye ili utopiya? [Roan Biopolymers: salvation or utopia?]. Plasticheskiye massy - Plastics 5-6: 63-66 [in Russian].

11. Lukanina YK, Khvatov AV, Kolesnikov NN, Korolev AV, Popov AA, et al. (2007) Termo i fotookisleniye biodestruktiruyemykh kompozitsii na osnove polietilena i prirodnykh napolniteley [Thermo and photooxidation of biodegradable compositions based on polyethylene and natural fillers]. Plasticheskiye massy Plastics. 5: 40-42 [in Russian]

12. Prachayawarakorn J, Pomdage W (2014) Effect of carrageenan on properties of biodegradable thermoplastic cassava starch/low-density polyethylene composites reinforced by cotton fibers. Mater Design 61: 264-269. Link: https://bit.ly/34gg20r

13. Pantyukhov PV, Popov AA, Monakhova TV, Nikolaeva SG (2013) Destruction of composite materials made of LDPE and lignocellulosic fillers. J Balk Tribol Assoc 19: 467-475. Link: https://bit.ly/36ZfM86

14. Wang YZ, Yang KK, Wang XL, Zhou Q, Zheng CY, et al. (2004) Agricultural application and environmental degradation of photo-biodegradable polyethylene mulching films. J Polym Environ 12: 7-10. Link: https://bit.ly/3m1kjLC

15. Orden MU, Montes JM, Urreaga J, Bento A, Ribeiro MR, et al. (2015) Thermo and photo-oxidation of functionalized metallocene high density polyethylene: Effect of hydrophilic groups. Polym Degrad Stabil 111: 78-88. Link: https://bit.ly/2W1M1gF

16. Yusak NAM, Mohamed R, Ramli MA (2014) Mechanical Analyses of Polyethylene/Polypropylene Blend with Photodegradant. J Appl Sci Agric 9: 300-305. Link:

Citation: Turdikulov IH, Mamadiyorov BN, Saidmuhammedova MQ, Atakhanov AA (2020) Obtaining and studying properties of biodestructable composite films based on polyethylene. Open Journal of Chemistry 6(1): 030-036. DOI: https://dx.doi.org/10.17352/ojc.000021 
17. Nikolic V, Velickovic S, Popovic A (2014) Biodegradation of polystyrene-graftstarch copolymers in three diferent types of soil. Environ Sci Pollut Res Int 21 9877-9886. Link: https://bit.ly/39XoQfJ

18. Mandal DK, Bhunia H, Bajpai PK, Bhalla VK (2017) Thermal degradation kinetics and estimation of lifetime of radiation grafted polypropylene flms. Radiat Phys Chem 136: 1-8. Link: https://bit.ly/373raju

19. Sunil S, Sanjeev A, Haripada B (2020) Biodegradation kinetic modeling of acrylic acid grafted polypropylene during thermophilic phase of composting. Iranian Polymer Journal 29: 735-747. Link: https://bit.ly/372Xdjr

20. Raj M, Savaliya R, Joshi S, Raj L, Keharia H (2019) Biodegradability, thermal, chemical, mechanical and morphological behavior of LDPE/pectin and LDPE/ modifed pectin blend. Polym Bull 76: 5173-5195. Link: https://bit.ly/3gvinJW

21. Shabarin AA, Shabarin AA, Vodyakov VN (2016) Polucheniye biorazlagayemykh kompozitsionnykh materialov na osnove polietilena i funktsionalizirovannogo metodom alkogoliza sopolimera etilena s vinilatsetatom [Obtaining biodegradable composite materials based on polyethylene and alcoholfunctionalized ethylene-vinyl acetate copolymer]. Vestnik Mordovskogo universiteta - Bulletin of the University of Mordovia 26: 259-268.

22. Yakubu MK, Musa MB, Mukaila J (2010) Degradation and Moisture Absorption Study of Potato-starch Linear Low Density Polyethylene Blend. Nigerian Journal of Basic and Applied Science 18: 126-129. Link: https://bit.ly/39Xp3Q3

23. Cavdar AD, Mengeloğlu F, Karakus K (2011) Effect of boric acid and borax on mechanical, fire and thermal properties of wood flour filled high density polyethylene composites. Measurement 60: 6-12. Link: https://bit.ly/39Z0Tom

24. Kolesnikova NN, Lukanina Yu.K, Popov AA (2012) Investigation of biodegradation of the compositions based on polyethylene, ethylene-vinyl acetate copolymer and natural rubber. Deformation and Destruction of Materials 7: $33-36$
25. Matet M, Heuzey MC, Ajji A, Sarazin P (2015) Plasticized chitosan/polyolefin films produced by extrusion. Carbohyd Polym 117: 177-184. Link: https://bit.ly/3m4Kcdt

26. Rogovina S, Aleksanyan K, Prut E, Gorenberg A (2013) Biodegradable blends of cellulose with synthetic polymers and some other polysaccharides. European Polymer Journal 49: 194-202. Link: https://bit.ly/3gzfQyk

27. Toupe JL, Trokourey A, Rodrigue D (2014) Simultaneous optimization of the mechanical properties of postconsumer natural fiber/plastic composites: phase compatibilization and quality/cost ratio. Polymer Composites 35: 730746. Link: https://bit.ly/2ICKdYq

28. Foulk JA, Wayne YC, Akin DE, Dodd RB, Layton PA (2006) Analysis of flax and cotton fiber fabric blends and recycled polyethylene composites. J Polym Environ 14: 15-24. Link: https://bit.ly/3mZe63Y

29. Arkatkar A, Arutchelvi J, Sudhakar M, Bhaduri S, Uppara PV, et al. (2009) Approaches to Enhance the Biodegradation of Polyolefins. Open Environmental Engineering Journal 2: 68-80. Link: https://bit.ly/3gxTttf

30. Vasilenko A Yu (2010) Vliyaniye metodov smesheniya na strukturu i svoystva polimernykh smesey na osnove polietilena nizkoy plotnosti [Influence of mixing methods on the structure and properties of polymer mixtures based on low density polyethylene]. Dis. ...kand. khim. nauk - Diss. of PhD [in Russian]

31. Lipatov YuS (1991) Fiziko-khimicheskiye osnovy napolneniya polimerov [Physicochemical fundamentals of polymer filling]. M.: Khimiya [in Russian].

32. Mastalygina $Y$ (2015) Struktura, svoystva i biorazlagayemost' troynykh kompozitsiy - polipropilen, polietilen nizkoy plotnosti i prirodnyye napolniteli [The structure, properties and biodegradability of ternary compositions are polypropylene, low density polyethylene and natural fillers]. Dis kand khim nauk - Diss of PhD [in Russian].

\section{Discover a bigger Impact and Visibility of your article publication with} Peertechz Publications

\section{Highlights}

* Signatory publisher of ORCID

* Signatory Publisher of DORA (San Francisco Declaration on Research Assessment)

* Articles archived in worlds' renowned service providers such as Portico, CNKI, AGRIS, TDNet, Base (Bielefeld University Library), CrossRef, Scilit, J-Gate etc.

* Journals indexed in ICMJE, SHERPA/ROMEO, Google Scholar etc.

* OAI-PMH (Open Archives Initiative Protocol for Metadata Harvesting)

* Dedicated Editorial Board for every journal

* Accurate and rapid peer-review process

* Increased citations of published articles through promotions

* Reduced timeline for article publication

Submit your articles and experience a new surge in publication services (https://www.peertechz.com/submission).

Peertechz journals wishes everlasting success in your every endeavours.

Copyright: @ 2020 Turdikulov IH, et al. This is an open-access article distributed under the terms of the Creative Commons Attribution License, which permits unrestricted use, distribution, and reproduction in any medium, provided the original author and source are credited.

Citation: Turdikulov IH, Mamadiyorov BN, Saidmuhammedova MQ, Atakhanov AA (2020) Obtaining and studying properties of biodestructable composite films based on polyethylene. Open Journal of Chemistry 6(1): 030-036. DOI: https://dx.doi.org/10.17352/ojc.000021 